\title{
Analysis and Implementation of Metode Collaborative Analysis Methods of Requirement and Design (CARD) on E-commerce Website in Indonesia
}

\author{
Oktariantoro Anggit $\mathrm{K}^{* 1}$, Angelina Prima $\mathrm{K}^{* 2}$, Erda Guslinar $\mathrm{P}{ }^{* 3}$ \\ * School of Computing, Telkom University \\ Bandung, Indonesia \\ 2 angelinadtelkomuniversity.ac.id \\ ${ }^{3}$ erda.guslinaregmail.com
}

\begin{abstract}
The development of internet in recent years caused a major prospect in online business. One of the businesses is e-commerce. E-commerce is an activity of selling and buying information through computer network. Website is a medium that can be used in e-commerce implementation. E-commerce website becomes an important part in supporting the companys success. Yet, there are many e-commerce websites that are not understandable by the user since the user cannot find out what they want. In addition, e-commerce website is still difficult to use. The users who cannot find what they want in e-commerce website will surely decrease the usability of the website. As a result, there must be a design planning which can be comprehended by the users to find the expected product easily. The Collaborative Analysis of Requirement and Design method can be used to solve the design problem. The method is one of the techniques in user centered design. The method focuses on users because in its process it involves the users, and the users are the the information source of this method. The information that is gained from the users can be taken form interview, questionairre and experimentation with component order. The result of this research gives contribution to the websites, that is advise to improve the website design so that the users can understand the working system and the design more comprehensively .
\end{abstract}

\section{Index Terms}

e-commerce, Collaborative Analysis of Requirement and Design, User Centered Design, Information

\section{INTRODUCTION}

The information technology, especially in computer nowadays, is used by all people. People use computer because it provides benefits in life especially to find information and to communicate. One of the media to search for the information and to communicate is through website. Therefore, the website is an important part in societys life. There are certain techniques that are required in the website making. Nevertheless, in making it, sometimes the developer does not consider the users who will use it so that the users can not understand the operation of the website. The kind of website that is difficult to understand for example, e-commerce website. They have problems in the website since it does not fulfill their expectations. This problem might be caused by the bad interface design. [?]

Therefore, the design in e-commerce website must be taken into consideration. The website design which is not understood by the users will decrease the usability of the website. Usability is a quality attribute which measures how easy the user interface is used [?]. To increase the website usability, we need a method that can give interface design which people can understand because the users of e-commerce website have different backgrounds. One of the methods which can be used for website design and development is Collaborative Analysis of Requirement and Design (CARD). This method is one of the User Centered Design techniques (UCD)[?]. CARD involves the users to decide the structure and organize the application components. The involvement of the users will fulfill the users need and will surely make the users understand more how to use the website. The advantage of this method is to facilitate the process of user engagement with a focus on website's User Interface. In this research, the method of Collaborative Analysis of Requirement and Design will be used as a method to make and analyze the expected e-commerce website that can increase usability because this method involves the users directly. In addition, an analysis of usability value in e-commerce website is conducted to know the strength and weaknesses of e-commerce website that is made in each component of usability quality.

\section{E-COMMERCE WEBSITE}

E-commerce website is a kind of website which has many components compared to another website. The components can be in form of pictures of sold items, buying mechanism, advertisement etc. E-commerce website is a medium that is used by 
e-commerce to trade through internet network. The mechanism of selling and buying goods or services that are organized in e-commerce website involves the activity of selling and buying product, service or information from the computer network[?]. There are two kinds of frequently implemented e-commerces i.e Business to Consumers (B2C) dan Business to Business (B2B)[?]. B2C is a kind of e-commerce in which the product, service or information provider is a company which is sold to the individual consumer. In contrast, B2B is a type of commerce in which the provider and buyer is companies.

\section{Collaborative Analysis Requirement And Design}

Collaborative Analysis Requirement and Design is a kind of method that is used in User Centered Design[?]. Therefore, this method also requires participation from probable users of the application or the system. This method is usually used to gain information in design process [?]. In addition, this method can give input about the navigation system, application structure, order of purchase, mechanism in the system, expected interface based on the card that we give to the users. The materials which are used in this method are like normal card which describes the occupation, object, person mental operation or interpersonal activity[?].

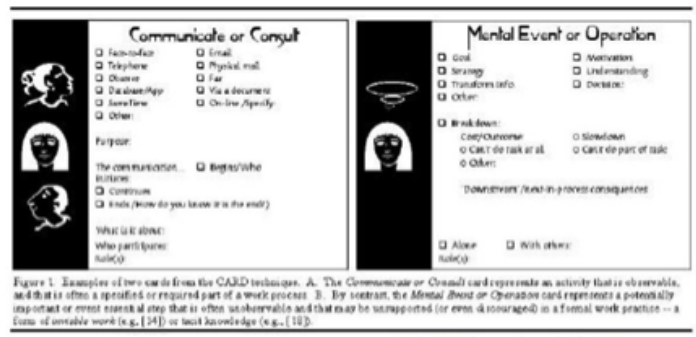

Fig. 1: Sample of CARD Method Card[?]

The CARD method can also be used to decide the activities order and application component location. CARD has a certain session in its technique i.e CARD sessions which consist of several phases. Following are the stages of CARD sessions.

- Introducing People

In this session the user not only mentions his/her name but also his/her workplace, hobby, job and how he/she works.

- Introducing Materials

In this session, a card will be introduced to the users. The card will represent the work activities or activity components and interface. In this session, the users will use the card to decide the order of activities which will explain how the activities are conducted. They can also comment so they can understand how the work is done. In addition they can know the activity context [?].

- Introducing Practices

In this session, there will exploration and clarification on the the faced problems. This session does not focus on the users but on the problems. It is also expected that the problems can be solved[?].

- Doing the work of the session

There are three sessions in this stage, firstly participatory analysis session in which the users describe their job and are given feedback. Secondly, participatory design session is the session in which the users explain the their current job or give the idea about innovation in doing the job, job relationship and technology. Thirdly, participatory assessment. It is a session which the evaluation is conducted in terms of achievement and purpose of the activity[?].

In Card Method there is a respective layer in which the users are involved directly with card and can give feedbcak about different card with general card sorting. The first layer is an observation towards the activities and worksteps of general process.

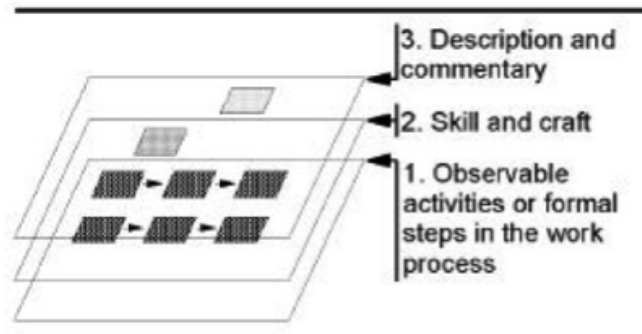

Fig. 2: CARD Process

The second is skill and craft which is related to the job details, tools usage and result decision. The third is description and 
comments of previous achieved result.

CARD method can be done with the followings:

- Open Card Sorting

The users are given paper which shows the comnent pictures without initialization of group component. The developer can directly assign the users to describe the componen grouping [?]

- Closed Card Sorting

The users are given paper which shows the picture of components which are used by developer to start forming a component primary group. Later, the users arrange the paper to primary group with needs and expectations[?].

\section{DESIGN}

\section{A. CARD Method General Modelling}

In developing the e-commerce website (in the final workstep), there are several stages in accordance to CARD method. The session or stage in CARD are Introducing People, Introducing Materials, Introducing Practice dan Doing the work sessions. Previously, the stages and the description have been explained. The execution of of each stage will be explained later. The first stage is Introducing People will be started by filling out the questionairre of respondent profile, Introducing Materials also uses a questionairre to take needed information while Introducing Practice uses interview medium to the respondents and finally Doing the work sessions is conducted to test the e-commerce website which is used with usability test.

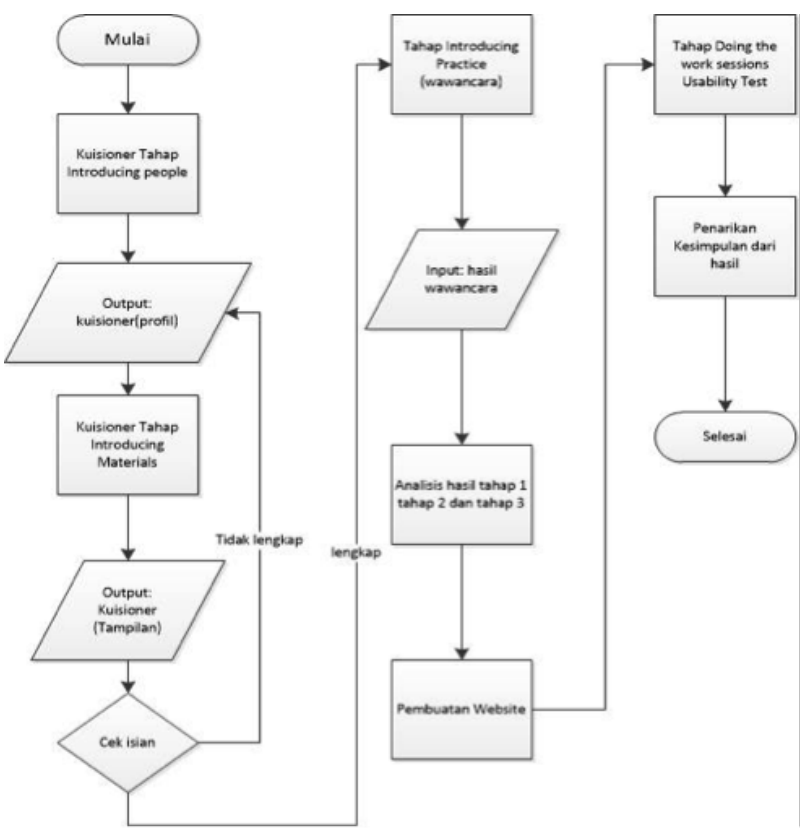

Fig. 3: CARD Process

\section{B. Introducing People Stage}

In the Introducing People Stage, the expected result is respondent profile (the respondents that are involved in e-commerce website). In this stage it is also expected to understand the respondents and their experiences.

Preparation for the Introducing People Stage begins by constructing a questionnaire containing several questions for respondents. The first question is a question about the respondent profile data. Furthermore, regarding the respondents' experience of ecommerce websites.

The questions that are arranged then changed into online questionairre. The online questionairres are used to help the data collection. Furthermore, the respondent choice uses purposive sampling which decides the respondents based on certain purposes since the outcome of this task is e-commerce website so the respondent poll is decided by educated ones and are used to use website especially e-commerce website. The author decides the requirements for the selected respondents with criteria of 16-35 years, are used to use the website and with junior high level of education. After the online questionairre is ready, the questionairre is given to the respondent. The minimum respondents are 30 . Because the respondents for usability test with purposive sampling does not require many respondents. In this stage, the online questionairre is spread along with the next step i.e Introducing Materials. The result and the solution of this stage will be explained later. 


\section{The Stage of Introducing Materials}

The stage of introducing material is focused on the introduction to the cards that are used to gain information from the respondents. The card that is used is interface example of e-commerce website which becomes the references. E-commerce website that becomes reference is lazada.co.id, zalora.co.id and bhinneka.com. The reference websites are chosen based on their ranks in alexa.com which is the website traffic analyzer. The three websites have the highest ranks among other e-commerce websites of business to consumers when the autohor accessed alexa in in January 2014. Therefore the three websites are choosen as the reference.

The preparation for introducing material stage is almost the same as the previous stage. In this stage, the first thing to do is preparing the questions for the included content in each part of e-commerce website. For example, the content on homepage, login, register of the e-commerce website. In addition, the questions about the problems that are faced by the respondents in each part of e-commerce website related to the next step Introducing Practice. Afterwards, the preparation which is done is reference taking of the interface from e-commerce website reference. After the materials needed in the stage of Introducing Material collected, the next stage is making online questionairre. Here, the online questionairre becomes integrated with the previous stage. After the online questionairre formed, the questonairre is spread to the respondents to be filled. Next, the data that are gained are filled and categorized. Furthermore, the data are analyze ro get a solution for e-commerce website design. The data and the solution given in this stage will be explained later.

\section{The Stage of Introducing Practice}

Introducing Practice is a stage which focuses on clarification of the problems or difficulties that are faced by the respondents with the visited website. In this stage, the respondents feedback is also expected in forms of solution and innovation that might be applied in the future e-commerce website.

The preparation for this stage is colleting the problems that are gained from the previous stage i.e introducing materials. Next, the collection othe questions about the problems that are faced, the solutions and the innovation that can be implemented in e-commerce.

This stage uses the interview media to gather the information. Thus, the questions provided are the interview questions. As explained previously, this stage is the clarification of the problems faced by respondents. Consequently, the interview is used to get more closely to the repondents and to make the respondents more open to to answer the questions since they talk directly with the author.

\section{E. The stage of Doing the Work Sessions}

This stage is the last stage of CARD method. In this stage, the respondent is asked to mention his/her job. In addition, the innovation from the respondents are expected. The evaluation that is used in this stage is usability test in order to know the usability level and the acceptance of website made by the respondents.

The preparation in this stage is initiated by the arrangement of the tasks which are given by the respondents and the questionairre questions arrangement of custoners satisfaction based on usability aspect. The detail explanation will be given in the evaluation of e-commerce website.

\section{QUeSTIONAIRRE RESUlT}

\section{A. Respondents Profile}

Respondents profile is a result of the Introducing People. The respondents profile of who participate in this research has some requirements : are used to access website, are at least 16 years old and has an experience with e-commerce website or online transaction. In this stage, there are 32 respondents. The following are respondents profile from questionairre in ??.

TABLE I: Respondents Profile

\begin{tabular}{|c|c|c|c|c|c|c|}
\hline \multirow{2}{*}{ Information } & \multicolumn{2}{|c|}{ Age } & \multicolumn{2}{c|}{ Sex } & \multicolumn{2}{c|}{ Education } \\
\cline { 2 - 7 } & under 21 y.o. & 21 y.o. and above & Male & Female & High School & University \\
\hline Number of people & 9 & 23 & 24 & 8 & 27 & 5 \\
\hline
\end{tabular}

\section{B. Respondents Experience}

This part is one of Introducing People stage to understand respondents. In this part, the experience of respondents on ecommerce website is presented. Based on the questionairre there are 3 respondents who never tried online transaction but already visited e-commerce website. Meanwhile, Figure ?? shows the number of transactions of respondents who filled out the questionairre : The experience about e-commerce website which are visited by the customers can be seen in Figure ??. From the result of three questionairre it can be observed that the respondents who filled out the questionairre are proper to give feedback to website design. There were $91 \%$ respondents who did the online transaction, $63 \%$ who did the transactions 


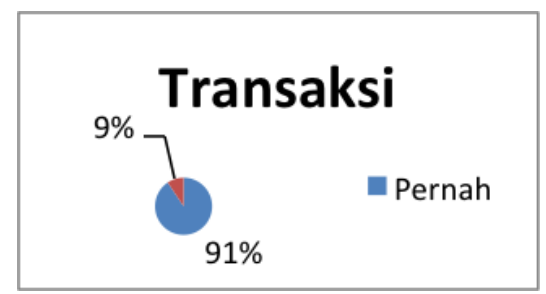

Fig. 4: Online Transaction

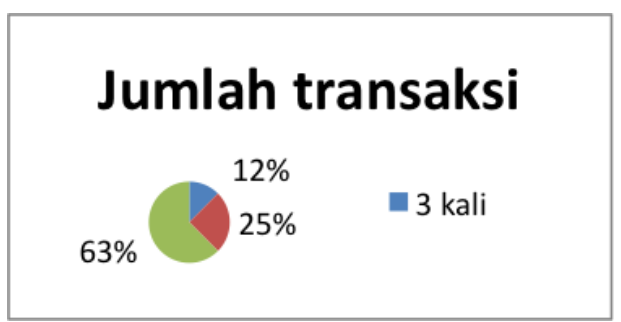

Fig. 5: Number of transactions

more than three times and visited all the e-commerce website which become references in the design. In terms of respondents experience about their convenience, can be seen in Figure ??. The result shows that respondents still feel unconvenient when they access the websites. The things that raise the inconvenience are shown in Figure ??. Also, the reasons of respondents visit e-commerce website can be seen in Figure ??.

\section{Display}

This part is the stage of Introducing Materials. In this stage the e-commerce website components and design of display are presented. The components which are discussed in this part are the components such as homepage, login, register, account profile, product, product details, checkout or shopping cart, payiment process, order details, payment confirmation, and tracking order. The cmponents on webpages on the e-commerce websites can be seen in ??.

\section{Difficulties}

The problems that the respondents face based on the questionairre given are shown in ??.

\section{E. Interview Result}

Interview is a part of Introducing Practice. In the interview, there are some questions given to respondents based on the problems resulted from questionairre stage and the possible innovation for e-commerce and the activity orders by card through the website. The problems or difficulties resulted from the interview can be seen in ??.

Besides the difficulties and problems faces while accessing the websites, the interview stage also seeks to find the expected innovation by the respondents who are experienced with e-commerce website. The innovation expected by the respondents are shown in ??.

\section{A. The stage of Introducing People}

\section{IMPLEMENTATION}

In this stage, the questionairre is given to the respondents about the e-commerce website. The scope of the questionairre is identifying the respondents trough filling out the profile data and also the experience of respondents of the e-commer website based on the transactions number.

\section{B. The stage of Introducing Materials}

In this stage the questionairre is also given to the respondents along with the previous stage. The scope of this questionairre is interface display and task on the website. 


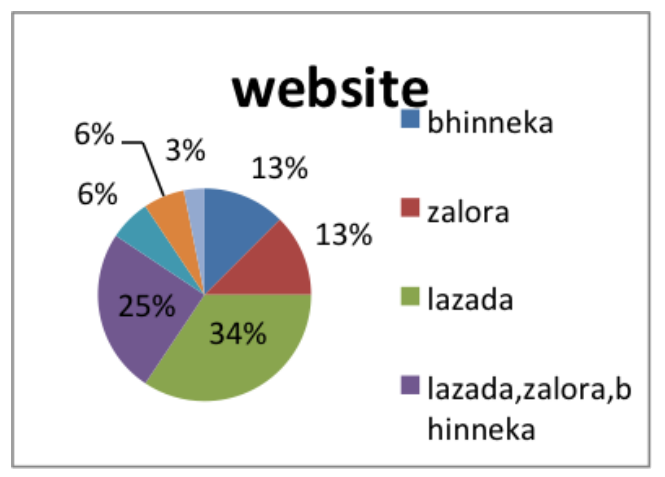

Fig. 6: Website e-commerce

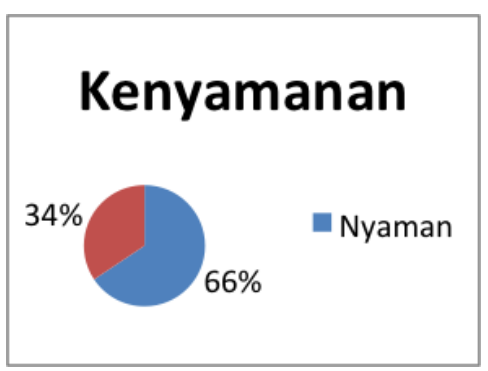

Fig. 7: Kenyamanan Responden

\section{The stage of Introducing Practice}

In the stage of Introducing Practice, an interview is done with the respondents. The interview is about the problems when they access the e-commerce website and the card order or activities components on the e-commerce website. In this stage the respondents are given some questions about the faced problems and the expected solutions. The result is used for consideration in the website design. This stage is a part of doing the work session for the innovation that is given by the respondent for the e-commerce website. The Introducing People stage focuses on problems and expected solutions by the respondents.

\section{The Design of Product Purchase Process \\ E. The Design of Website Interface}

The design of homepage is made simply with some banners and products which are displayed so that the website can be easily identified as e-commerce website. The content on homepage is suited with the feedback given by the users. Some of them are banner, product, login, register, category, help and bank which serves the payment.

\section{F. The stage of Doing the work sessions}

In this stage, the questionairre is given to the respondents. The respondents would do a task first and later answers some questions which represent 5 aspects of usability test.

\section{PTESTING}

The testing in this research is done by usability test to know the level of quality and the acceptance of respondents on the website which is made. Reliability and validity test is also done on the questionairre used in this research. The reliability and validity of the test is done to know the validity of the questionairre as well as the result accuracy and the result consistency of the questionairre. The purpose of the website test is based on the research purpose i.e receiving feedback from repondents in e-commerce website design, making e-commerce website based on the respondents and testing the e-commerce website using the usability test which is expected to gain high usability.

The tasks are describe as follows :

- Task 1. Register as a member and log in.

Users are asked to website by finding the register button and fill out the registration form. After the users register they are required to $\log$ out and then $\log$ in again with the member data register. 


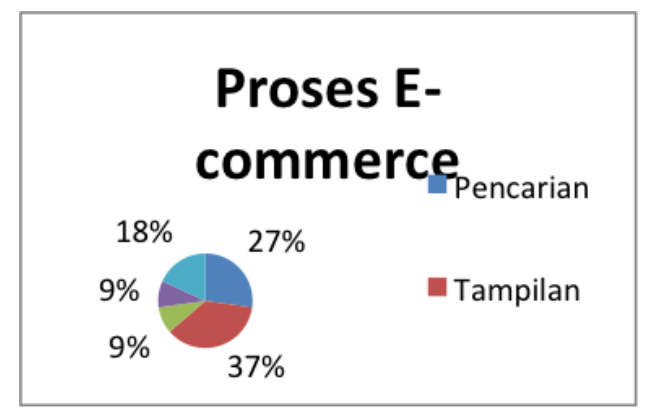

Fig. 8: Proses Kurang Nyaman menurut responden

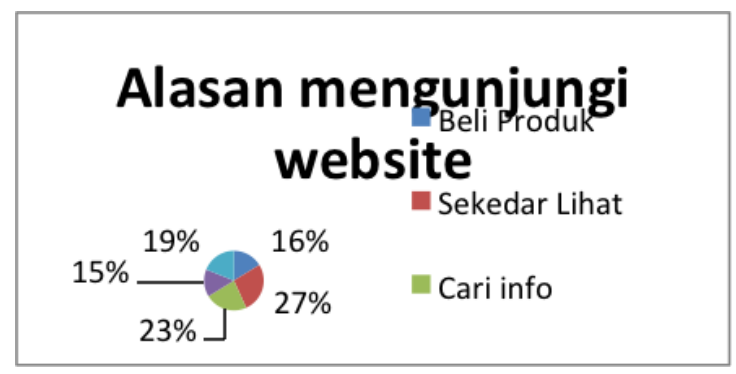

Fig. 9: Alasan mengunjungi website

- Task 2. Log in as a member and log out and log in again

Users are asked to $\log$ in as a website member. They begin by finding out log in button and fill out the form, login to enter. After they enter, they are asked to find logout button and then log in again.

- Task 3. Select the product based on the category

Users are asked to select certain products. They begin by selecting the category in the website and see if the category can help them to find the product on the web.

- Task 4. Find the product through search box

Users are asked to find a product. They begin by entering the key words to find the product in search box and see the result there.

- Task 5. Put the product into the cart and delete the product, fill and continue to the next process

Users are asked to put a product into the cart, delete the product from the cart and when they are successful they need to put back the prouct into the cart and continue to the next process.

- Task 6. Doing the payment

Users are asked to do the payment process. They firstly see the detail of their order and fill out the from. After taht, they choose the way of product payment and finally they confirm the product payment with the ordered product.

After the task is done by the respondents. The next step is answering the questions which represent the five aspects of usability. They are Lear=Learnability, Eff= Efficiency, Err=Errors, Memo=Memorability, Satis=Satisfication.

Each question is given choices of answers which range from 1-5. They will present the usability score. The choices are $=$ $\mathrm{SD}=$ Strongly Disagree, $\mathrm{D}=$ Disagree, $\mathrm{A}=$ agree, $\mathrm{SA}=$ strongly agree, $\mathrm{RSA}=$ Really Strongly Agree. Range of answers choices score $\mathrm{SD}=1, \mathrm{D}=2, \mathrm{~A}=3, \mathrm{SA}=4$ dan $\mathrm{RSA}=5$.

\section{A. Validity Test}

The validity test conducted is the usability test questionairre. The validity test uses the technique of corrected item-total. The questionairre consists of ten questions with 30 respondents [?].

From question number 1 to number 10 it can be seen that the corrected item-total correlation has a value more than 0.3 and a value of alpha cronbach close to 1 . The result from SPSS indicates that the usability of the questionairre in this research is valid with the value above 0.3 .

\section{B. Reliability Test}

Reliability test is done to know the accuracy and consistency of the questionairre result. The questionare which is tested is usability test questionairre. The questionairre consists of 10 questions with 30 respondents. The reliability test uses split-half technique since it only tests a single datum or the result of a once conducted test. This technique divides the data into equal 
TABLE II: Tampilan

\begin{tabular}{|c|c|c|c|c|c|}
\hline No. & Page & Component & No. & Page & Component \\
\hline \multirow[t]{2}{*}{1} & \multirow[t]{2}{*}{ Homepage } & $\begin{array}{l}\text { Banner } \\
\text { Product } \\
\text { Login } \\
\text { Register } \\
\text { Contact } \\
\text { Search box } \\
\text { Cart }\end{array}$ & 2 & Register & $\begin{array}{l}\text { Name } \\
\text { Gender } \\
\text { Captcha } \\
\text { Birthdate } \\
\text { Newsletter } \\
\text { E-mail }\end{array}$ \\
\hline & & $\begin{array}{l}\text { Payment } \\
\text { Brand } \\
\text { Delivery Service } \\
\text { Facility } \\
\text { Service } \\
\text { Category }\end{array}$ & 3 & Login & $\begin{array}{l}\text { E-mail Field } \\
\text { Password Field } \\
\text { Register } \\
\text { Help }\end{array}$ \\
\hline 4 & Product & $\begin{array}{l}\text { Discount } \\
\text { Description } \\
\text { Purchase Button } \\
\text { Spesification } \\
\text { Category }\end{array}$ & 5 & Account Profile & $\begin{array}{l}\text { Profile Account } \\
\text { Account Information } \\
\text { Address Book } \\
\text { Order History } \\
\text { Payment } \\
\text { Order Tracking }\end{array}$ \\
\hline 6 & Product Details & $\begin{array}{l}\text { Discount } \\
\text { Spesification } \\
\text { Number of Stock } \\
\text { Product Information } \\
\text { Related Product }\end{array}$ & 7 & Order Details & $\begin{array}{l}\text { Address } \\
\text { Payment Methods } \\
\text { Order Status } \\
\text { Product Details } \\
\text { Order Number } \\
\text { Delivery }\end{array}$ \\
\hline 8 & Cart & $\begin{array}{l}\text { Quantity } \\
\text { Discount } \\
\text { Spesification } \\
\text { Coupon/Gift Card } \\
\text { Delivery Estimation }\end{array}$ & 9 & Payment & $\begin{array}{l}\text { Delivery Address } \\
\text { Payment Method } \\
\text { Short Description of Order }\end{array}$ \\
\hline 10 & Payment Confirmation & $\begin{array}{l}\text { Order Number } \\
\text { E-mail } \\
\text { Name } \\
\text { Bank } \\
\text { Transfer Vaue } \\
\text { Bank Account Number }\end{array}$ & 11 & Tracking Order & $\begin{array}{l}\text { Order Number } \\
\text { Delivery Status }\end{array}$ \\
\hline
\end{tabular}

TABLE III: Problems or difficulties from questionairre

\begin{tabular}{|c|l|l|}
\hline No & \multicolumn{1}{|c|}{ Page } & \multicolumn{1}{|c|}{ Problems/Difficulties } \\
\hline 1 & \multirow{2}{*}{ Homepage } & Finding through Search \\
\cline { 3 - 3 } & & Finding through Category \\
\cline { 3 - 3 } & & the display is to compicated \\
\hline 2 & \multirow{2}{*}{ Login } & The customers must have an account \\
\cline { 3 - 3 } & & Captcha code is not clear \\
\hline 3 & Register & Too many data are required to fill \\
\hline 4 & Product & - \\
\hline 5 & Product Details & The information of the product is incomplete, there is no information about the stock number \\
6 & Checkout & - \\
\hline 7 & Category & the category does not show the expected product \\
\hline 8 & Detail order & - \\
\hline 9 & Payment & Which bank can serve \\
\hline
\end{tabular}

size. In this usability questionairre they are part a which consists of questions number 1-5 and part $\mathrm{b}$ which consists of questions number 6-10.

The result of reliability test with SPSS shows that the questioanairre result is reliable based on the equal length Spearman Brown with the value of 0.932 which is more than 0.700 .

\section{The Result of Task Usability Testing}

In the task usability testing, $100 \%$ result is gained from the respondents. They all can do the given tasks. The given tasks are task1-task6. The number of respondents who try is 30 persons. 
TABLE IV: The Result of The Interview

\begin{tabular}{|c|c|c|}
\hline No & Page & Problems/Difficulties \\
\hline \multirow[t]{5}{*}{1} & \multirow[t]{5}{*}{ Homepage } & Finding through Search presents innappropriate product \\
\hline & & Finding through category does not present as the category \\
\hline & & The display is too complicated \\
\hline & & The bank which serves must be presented \\
\hline & & The menu does not help the users to find something needed easily \\
\hline \multirow[t]{2}{*}{2} & \multirow{2}{*}{ Login } & must have an account \\
\hline & & Captcha code for login invisible, the user cannot find the login button \\
\hline 3 & Register & To many required data to fill in registration form \\
\hline 4 & Product & - \\
\hline 5 & Product Details & The infromation of the product is incomplete and there is no information ofstock number \\
\hline 6 & Checkout & - \\
\hline 7 & Category & The category does not present the expected product \\
\hline 8 & Detail Order & - \\
\hline \multirow[t]{4}{*}{9} & \multirow[t]{4}{*}{ Payment } & Which banks serve \\
\hline & & There is no certain delivery service \\
\hline & & The change of payment method which is difficult \\
\hline & & Address confirmation to ensure the address is true in the last payment \\
\hline
\end{tabular}

TABLE V: Expectation of Innovation from the Interview

\begin{tabular}{|c|l|}
\hline No & \\
\hline 1 & E-money for the transaction done \\
\hline 2 & Money deposit for transaction in e-commerce website \\
\hline 3 & The display is made more simple \\
\hline 4 & Rating for the seller or product \\
\hline 5 & The betterment of menu and search to find the expected product easily \\
\hline 6 & Stock number is displayed for considering the product purchase by the buyer \\
\hline 7 & The range of price for category of product searching \\
\hline 8 & Operator for special website to deal with the payment if there is a mistake done by operator \\
\hline 9 & Direct interaction with operator through the video for transaction \\
\hline 10 & Purchase by SMS \\
\hline 11 & Expand the extent of COD \\
\hline
\end{tabular}

TABLE VI: Task Usability Test

\begin{tabular}{|c|l|}
\hline No & \\
\hline 1 & Register as a member and log in \\
\hline 2 & Log in as a member and log out and log in again \\
\hline 3 & Select the product based on the category \\
\hline 4 & Find the product through search box \\
\hline 5 & Put the product into the cart and delete the product, fill and contniue to the next process \\
\hline 6 & Doing the payment \\
\hline
\end{tabular}

TABLE VII: Questions of Usability Test

\begin{tabular}{|c|c|c|c|c|c|c|}
\hline \multirow[t]{2}{*}{ No } & \multirow[t]{2}{*}{ Questions } & \multicolumn{5}{|c|}{ Quality Aspects of Usability } \\
\hline & & Lear & Eff & Memo & Err & Satis \\
\hline 1 & They type of website can be identified from the firt display. & $\sqrt{ }$ & & & & $\sqrt{ }$ \\
\hline 2 & You can find the product you want by category selection & & $\sqrt{ }$ & $\sqrt{ }$ & & $\sqrt{ }$ \\
\hline 3 & The language and the font are readable and easy to understand & & & & $\sqrt{ }$ & $\sqrt{ }$ \\
\hline 4 & The color on the web is convenience to see & & & & & $\sqrt{ }$ \\
\hline 5 & You can understand the information on each page & & $\sqrt{ }$ & $\sqrt{ }$ & & \\
\hline 6 & The symbols that are used are understandable & & & & $\sqrt{ }$ & $\sqrt{ }$ \\
\hline 7 & Picture and product banner are convenient to see & & & & & $\sqrt{ }$ \\
\hline 8 & The product you find through searchbox can be found & $\sqrt{ }$ & $\sqrt{ }$ & & $\sqrt{ }$ & $\sqrt{ }$ \\
\hline 9 & The product checkout is easy to do & $\sqrt{ }$ & & & $\sqrt{ }$ & $\sqrt{ }$ \\
\hline 10 & The payment process is easy to do & $\sqrt{ }$ & & & $\sqrt{ }$ & $\sqrt{ }$ \\
\hline
\end{tabular}

\section{The Result of Respondence Satisfaction Questionairre Testing}

The result of respondents answer in respondents satisfaction questionairre is in Table ??. SD=Strongly Disagree, D=Disagree, $\mathrm{A}=$ agree, $\mathrm{SA}=$ strongly agree, $\mathrm{RSA}=$ Really Strongly Agree. Range of answers choice score $\mathrm{SD}=1, \mathrm{D}=2, \mathrm{~A}=3, \mathrm{SA}=4 \mathrm{dan} \mathrm{RSA}=5$.

Based on the questionairre answer percentage above, the usability score recapitulation is presented in Table ??. 

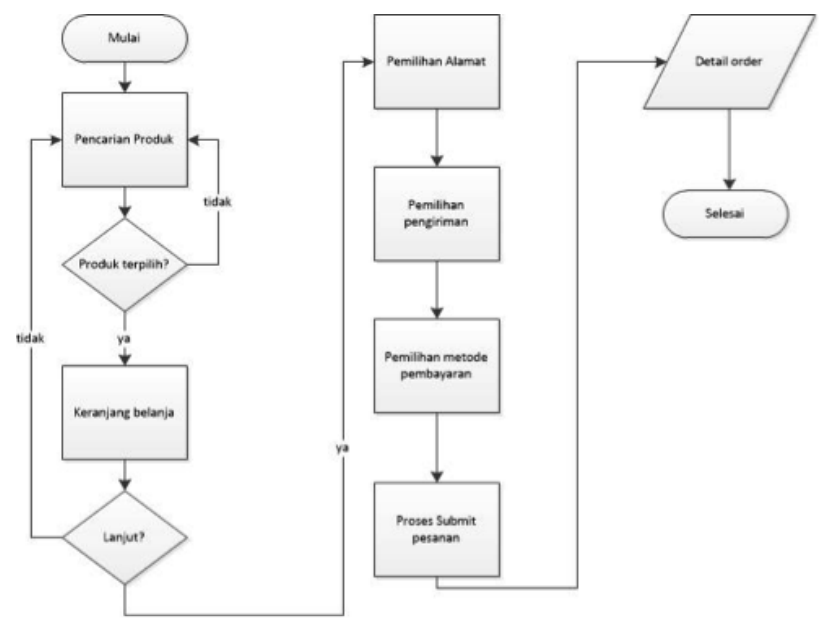

Fig. 10: The Design of Product Purchase Process

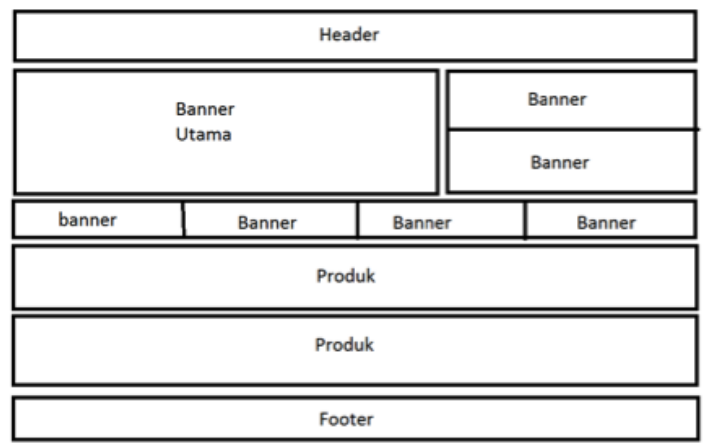

Fig. 11: The design of Homepage

TABLE VIII: Respondents Answers

\begin{tabular}{|c|c|c|c|c|c|}
\hline $\begin{array}{c}\text { Quenstion } \\
\text { number }\end{array}$ & SD & D & A & SA & RSA \\
\cline { 2 - 6 } & 1 & 2 & 3 & 4 & 5 \\
\hline 1 & $0 \%$ & $0 \%$ & $20 \%$ & $40 \%$ & $40 \%$ \\
\hline 2 & $0 \%$ & $0 \%$ & $16.67 \%$ & $50 \%$ & $33.33 \%$ \\
\hline 3 & $0 \%$ & $0 \%$ & $20 \%$ & $40 \%$ & $40 \%$ \\
\hline 4 & $0 \%$ & $0 \%$ & $10 \%$ & $56.67 \%$ & $33.33 \%$ \\
\hline 5 & $0 \%$ & $0 \%$ & $26.67 \%$ & $63.33 \%$ & $10 \%$ \\
\hline 6 & $0 \%$ & $0 \%$ & $16.67 \%$ & $50 \%$ & $33.33 \%$ \\
\hline 7 & $0 \%$ & $0 \%$ & $20 \%$ & $56.67 \%$ & $23.33 \%$ \\
\hline 8 & $0 \%$ & $0 \%$ & $36.67 \%$ & $23.33 \%$ & $40 \%$ \\
\hline 9 & $0 \%$ & $0 \%$ & $20 \%$ & $40 \%$ & $40 \%$ \\
\hline 10 & $0 \%$ & $0 \%$ & $23.33 \%$ & $26.67 \%$ & $50 \%$ \\
\hline
\end{tabular}

TABLE IX: Usability Score

\begin{tabular}{|c|l|c|}
\hline No & \multicolumn{1}{|c|}{ Attributes } & Score \\
\hline 1 & The website types can be recognized from the first display & 4.2 \\
\hline 2 & You can find the expected product by choosing the category & 4.16 \\
\hline 3 & The language and the letters are readable and easy to understand & 4.2 \\
\hline 4 & The colors in the website are convenient to see & 4.23 \\
\hline 5 & You can understand the information in each page & 3.83 \\
\hline 6 & The symbols used are easy to understand & 4.16 \\
\hline 7 & The pictures and the product banner are convenient to see & 4.03 \\
\hline 8 & The product you search through box search can be found & 4.03 \\
\hline 9 & Tthe product checkout process can be done easily & 4.2 \\
\hline 10 & The payment process can be done easily & 4.26 \\
\hline
\end{tabular}




\begin{tabular}{|l|r|r|r|r|}
\multicolumn{7}{|c|}{ Item-Total Statistics } \\
\hline & $\begin{array}{c}\text { Scale Mean if } \\
\text { item Deleted }\end{array}$ & $\begin{array}{c}\text { Scale } \\
\text { Variance if } \\
\text { Item Deleted }\end{array}$ & $\begin{array}{c}\text { Corrected } \\
\text { Item-Total } \\
\text { Correlation }\end{array}$ & $\begin{array}{c}\text { Cronbach's } \\
\text { Alpha if liem } \\
\text { Deleted }\end{array}$ \\
\hline skor1 & 37.13 & 19.292 & .652 & .845 \\
skor2 & 37.17 & 20.902 & .444 & .862 \\
skor3 & 37.13 & 20.326 & .484 & .859 \\
skor4 & 37.10 & 21.128 & .471 & .859 \\
skor5 & 37.50 & 21.569 & .420 & .863 \\
skor6 & 37.17 & 19.799 & .634 & .847 \\
skor7 & 37.30 & 20.355 & .568 & .852 \\
skor8 & 37.30 & 18.217 & .687 & .842 \\
skor9 & 37.13 & 19.154 & .675 & .843 \\
skor10 & 37.07 & 18.478 & .712 & .839 \\
\hline
\end{tabular}

Fig. 12: Validation Result

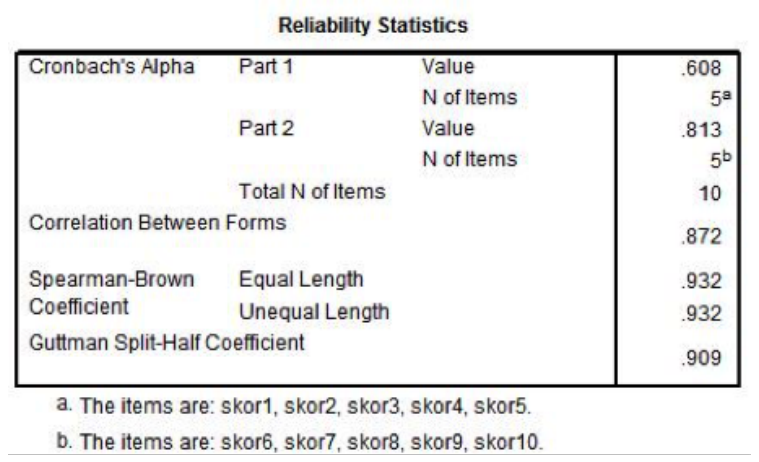

Fig. 13: Reliability Result

From the usability score recapitulation the average score of the users is 4.13 . This shows that the website is easy to use and understand. If we look at the five aspects of usability i.e learnability, memorability, efficiency, errors and satisfaction with the average score above 4 , the website application has already possesed those five aspects which are acceptable by the users.

\section{CONCLUSION}

Based on CARD method and its examination, there are some drawn conclusion :

1) The feedback from the users can be collected by a process in CARD method and gives feedback for the e-commerce website design.

2) The feedback from the users can be used as in developing e-commerce website.

3) Website e-commerce which is resulted has a high usability proven vy usability test which yields the average 4 of score and has five aspects of usability.

\section{REFERENCES}

[1] Dewa, Penyusunan Kuesioner.

[2] Fairfax County Department of Neighborhood and Community Services, Survey Questionnaire Design. Informational Brochure,2012.

[3] NN Group (2014 Jan.) [Online] Available: http://www.nngroup.com/articles/usability-101-introduction-to-usability/

[4] Jokela, T., Livari, n., vesa, T. , Using the ISO 9241-11 Definition of Usability in Requirements Determination:Case Studies.

[5] Karray, F., Alemzadeh, M., Saleh, J. A., Arab, M. N., "Human-Computer Interaction: Overview on State of the Art." in International Journal on Smart Sensing and Intelligent Systems, pp.137-159, 2008.

[6] Muller, M. J., "Layered Participatory Analysis:New Developments in the CARD Technique" in ACM, 2001.

[7] Munaiseche, C. P., "Pengujian Web Aplikasi DSS Berdasarkan pada Aspek Usability" in Orbith vol 8, pp.63-68, 2012.

[8] Purwati, Y., Standard Features of E-Commerce User Interface" in Researchers World, pp.77-87, 2011.

[9] Tongco, M. D., "Purposive Sampling as a Tool for Informant Selection" in Ethnobotany Research and Applications, pp.147-158, 2007.

[10] Triastuti, N., Krisnawati, L. D., Riyono, A. , "Implementasi CARD dalam Perancangan Program Bantu Pembelajaran Membaca" in Jurnal Informatika vol. 6 , pp.47-55, 2010.

[11] V.Srikanth, Dr.R.Dhanapal, P., "An Insight to Build an E-Commerce Website with OScommerce" in International Journal of Computer Science Issues, pp.332-343, 2011.

[12] van Kalsbeek, M.G., Interface Guidelines for E-commerce Checkouts.

[13] Wang, Y., Patel, D., "Comparative Software Engineering: Review and Perspectives" in Annals of Software Engineering pp.3-10

[14] Wen, J. H., Chen, H. G., Hwang, H.-G., "E-commerce Web site design: strategies and models" in Information Management and Computer Security, pp.5-12, 2011.

[15] Widiarso, W., Jessianti, Sutini, "Metode UCD (User Centered Design) Untuk Rancangan Kios Informasi Studi Kasus : Rumah Sakit Bersalin XYZ” in Algoritma vol. 3, pp.6-10, 2007. 